\title{
Effect of Some Organic and Mineral Fertilizer Applications on Growth and Productivity of Pomegranate Trees
}

\author{
Eman, E.K. Abd-Ella, ${ }^{1}$ S.S. Mervate ${ }^{2}$ and A.Z. Wafaa ${ }^{2}$
}

\begin{abstract}
This investigation was carried out during 2007 and 2008 growing seasons on six years old Arabi-pomegranate trees, grown in sandy clay loamy soil in a private farm located at Alexandria-Matrouh road, to study the effect of different fertilizers i.e., minerals (Ammonium Sulphate, Potassium Sulphate and Calcium Super Phosphate) at rate of $100 \%$ or $50 \%$ of the recommended dose or organic (humic acid or compost solely) or their combinations on growth, fruit set, yield, fruit quality and leaf minerals content during both seasons of study. The obtained results showed that, vegetative growth, fruit set, yield as weight or number of fruits /tree as well as fruit quality (average fruit weight, diameter, length, TSS and anthocyanine) and leaf $\mathrm{N}$ content were, generally, improved under all treatments as compared with control in both seasons. While, slight effect on leaf $P$ and $K$ content were noticed. The studied treatments decreased juice acidity and did not significantly affect V.C. and tannins content in both seasons. The striking treatments $50 \%$ of the recommended rate of NPK + organic matter (compost or humic acid) were most effective in improving all parameters when compared with other treatments. It is worthy to note that, using $50 \%$ of the recommended rate of NPK + organic matter (compost at $25 \mathrm{Kg}$ / tree or humic acid at 12.5 or $25 \mathrm{~g} /$ tree) had a similar effect to the treatment $100 \%$ of the recommended rate of NPK solely. Hence, it could be concluded that fertilizing pomegranate trees with $50 \%$ of the recommended rate of NPK + humic acid at higher rate $25 \mathrm{~g} /$ tree is the promising treatment under the same condition of our study. Moreover, it reduced half the amount of the recommended mineral fertilizers as well as soil pollution.
\end{abstract}

\section{INTRODUCTION}

Recently, there has been an increasing demand for pomegranate (Punica granatum L.) to meet the need of local as well as the foreign markets of some European and Arabic countries.

Nowadays a great attention is focused on minimizing the intensive amounts of mineral fertilizers, because of their harmful effect and high costs. Hence, organic fertilization is happening to have a great importance.

In sandy and sandy loam soils, organic fertilization is used to improve the physical, chemical and biological characteristics of the soil .Adjusting soil $\mathrm{pH}$, and

\footnotetext{
${ }^{1}$ El-Sabahia Hort. Res. Stat.Alex.

${ }^{2}$ El-Maamoura Botanical Garden

Hort. Res. Inst. Agricle. Res. Center, Giza, Egypt

Received septamper12, 2010, Accepted septamper 29, 2010
}

increasing the solubility and availability of nutrients $(\mathrm{P}, \mathrm{K}, \mathrm{Ca} \& \mathrm{Mg})$ and influence the plant growth and production (Pinton, et al.,1992). Compost is an organic fertilizer and soil amendment that provide plants with mineral nutrition and other benefits (Haggag, 1996) and gave the best fruit characteristics (Abd El-Naby, 2000). On the other hand, many commercial products containing humic acid (HA) have been prometed for use on various crops, Liu et al., (1998). Benefits ascribed to the use of humic acid, particularly in low organic matter, alkaline soil, include increasing nutrient uptake, tolerance to drought and temperature extremes, stimulating activity of beneficial soil microorganisms and availability of soil nutrients (Seen and Kingman, 1973 and Russo and Berlyn, 1990). Humic materials may also increase root growth in a manner similar to auxin (O'Donnell, 1973 and Petrovic et al., 1982). Humic substances are ubiquitous in the environment. Their importance in agriculture and soil sciences has been acknowledged for over 150 years, (Maggioni et al., 1987). Humic acid contains sulfur, nitrogen and phosphorus in varying amounts. It also contains metals such as $\mathrm{Ca}, \mathrm{Mg}, \mathrm{Cu}, \mathrm{Zn}$ etc. A substantial fraction of the mass of the humic acids is in carboxylic acid functional groups, which endow these molecules with the ability to chelate positively charged multivalent ions $\left(\mathrm{Mg}^{++}\right.$, $\mathrm{Ca}^{++}, \mathrm{Fe}^{++}$and most other "trace elements" of value to plants, as well as other ions that have no positive biological role, such as $\mathrm{Cd}^{++}$and $\mathrm{Pb}^{++}$). This chelation of ions is probably the most important role of humic acids with respect to living system (Purchase, 1997).

Accounting for the aforementioned aspects, this investigation was planned to study the effect of humic acid, compost and mineral fertilizers in the form of calcium super phosphate, potassium sulphate and ammonium sulphate as well as their combinations on vegetative growth, leaf chlorophyll and some mineral content, yield and fruit physical and chemical characters of Arabi pomegranate trees as a trial to reduce the costs of fertilizers, increase the yield and improve fruit quality.

\section{MATERIALS AND METHODS}

The present study was carried out during 2007 \& 2008 successive seasons on six years old Arabi 
pomegranate trees, grown in sandy clay loamy soil of a private farm located at Alex-Matrouh road and spaced at $5 \times 5$ meters apart. The physical and chemical properties of the experimental soil are presented in Table (1).

Nine treatments were used to evaluate soil application of $100 \%$ and $50 \%$ of the recommended doses of mineral NPK fertilization with or without organic fertilization as humic acid (HA) or compost (Nile compost) compared with the control trees which received organic fertilizer in the form of sheep manure at $15 \mathrm{~m}^{3}$ / feddan as follow:

$\mathrm{T}_{1}-$ Control (sheep manure at $15 \mathrm{~m}^{3} /$ feddan)

$\mathrm{T}_{2}-100 \%$ of the recommended doses of NPK $(2 \mathrm{Kg}$ ammonium sulphate $+1 \mathrm{Kg}$ potassium sulphate $+1 \mathrm{Kg}$ super phosphate) /tree

$\mathrm{T}_{3}-50 \%$ of the recommended doses of NPK $(1 \mathrm{Kg}$ ammonium sulphate $+0.5 \mathrm{Kg}$ potassium sulphate + $0.5 \mathrm{Kg}$ super phosphate) /tree

$\mathrm{T}_{4}$ - Compost (Nile compost) $25 \mathrm{Kg} /$ tree

$\mathrm{T}_{5}-$ Humic acid (hummer $86 \%$ potassium hummate) at $12.5 \mathrm{~g} /$ tree as soil application

$\mathrm{T}_{6}-$ Humic acid (hummer $86 \%$ potassium hummate) at $25 \mathrm{~g} /$ tree as soil application

$\mathrm{T}_{7}-50 \%$ of mineral fertilizers NPK $+25 \mathrm{Kg}$ compost

$\mathrm{T}_{8}{ }_{-50 \%}$ of mineral fertilizers $\mathrm{NPK}+12.5 \mathrm{~g}$ humic acid

$\mathrm{T}_{9}{ }_{5} 50 \%$ of mineral fertilizers NPK $+25 \mathrm{~g}$ humic acid

The mineral fertilization treatments were added as a percent of the recommended rate by Ministry of Agric.i.e. $2 \mathrm{Kg} /$ tree of ammonium sulphate $(20.6 \mathrm{~N})$ as a source of nitrogen and $1.0 \mathrm{Kg} /$ tree of potassium sulphate $\left(48 \% \mathrm{~K}_{2} \mathrm{O}\right)$ as a source of potassium per tree were added as soil application in three equal doses at February, April and June. $1.0 \mathrm{Kg} /$ tree calcium superphosphate $\left(15.5 \% \mathrm{P}_{2} \mathrm{O}_{2}\right)$ was added with $15 \mathrm{~m}^{3} /$ feddan organic (sheep manure) in December of both seasons. Mineral fertilizers were mixed with soil surface layer $(20 \mathrm{~cm}$ depth) surrounding the trunk till the external end of canopy shade. Organic fertilizers were applied in the form of compost at rate of 25 $\mathrm{Kg} /$ tree in January of each year. The chemical analysis of compost is shown in Table (2). Also, the hummer (86\% potassium hummate) was added at two concentrations (12.5 and $25 \mathrm{gm})$ per tree at the first week of February. The organic fertilizers were applied in two parallel ditches of $50 \mathrm{~cm}$ width and $30 \mathrm{~cm}$ depth. The ditches surrounded the tree from two directions in the end of canopy. In the $2^{\text {nd }}$ season, they were dug in the other two directions.
The experiment was set in Randomized Complete Block Design with replications for each treatment using three trees as a single replicate $(9$ treatments $\times 3$ replicates $\times 3$ trees $=81$ trees).

In each season of study (on early April), 20 new shoots (one year old) well distributed around periphery of each replicate tree ( 5 shoots toward each direction) were randomly selected, labeled and measured their length as well as the number of their leaves. The following parameters were used to evaluate the tested treatments:

\section{Vegetative growth:}

At the end of growing season, the selected shoots were measured to determine the average length $(\mathrm{cm})$ and number of leaves /shoot. Five leaves were collected randomly from the first mature leaves from the tip of the previously tagged shoots and their areas $\left(\mathrm{cm}^{2}\right)$ were measured and numbers of fruits / shoot were determined for fruit set percentage. Also, total leaf chlorophyll content was determined in the same fresh leaves according to the method described by Yadava (1986) using Minolta chlorophyll Meter Spad. 502 (Minolta Camera, LTD Japan).

\section{Yield and Fruit quality:}

The total yield $(\mathrm{kg})$ of each replicate tree was calculated using the average fruit weight (gm) and the total number of fruits per tree. On the $1^{\text {st }}$ August in both seasons, number of fruits per each experimental tree was counted. At harvesting time, on August $30^{\text {th }}$, in both seasons, five fruits were taken at random from each replicate to determine fruit quality expressed as average fruit weight $(\mathrm{gm})$, diameter $(\mathrm{cm})$ and length (cm). In juice of each fruit sample, total soluble solids (TSS) percentage was determined by a hand refractometer and the percentage of acidity was measured according to A.O.A.C. (1995). Vitamin C was determined by the titration with dichlorophenol indophenol blue dye and expressed as $\mathrm{mg}$ vitamin $\mathrm{C}$ $/ 100 \mathrm{ml}$ juice. Also, total anthocyanine content in fruit juice was determined as described by Hsia et al., (1965). Tannins content was measured in the juice by the method described by Winton and Winton, (1945).

\section{Leaf mineral content:}

A sample of five leaves was randomly selected from the middle part of non fruiting shoots of each replicate tree in both seasons. The selected leaves were washed with tap water, rinsed with distilled water and oven dried at $70^{\circ} \mathrm{C}$ to constant weight and then ground. The ground leaf samples were digested with sulfuric acid and hydrogen peroxide according to Evenhuis and Dewaard (1980). Suitable aliquots were taken for the determinations of N, P and K. Nitrogen and phosphorus 


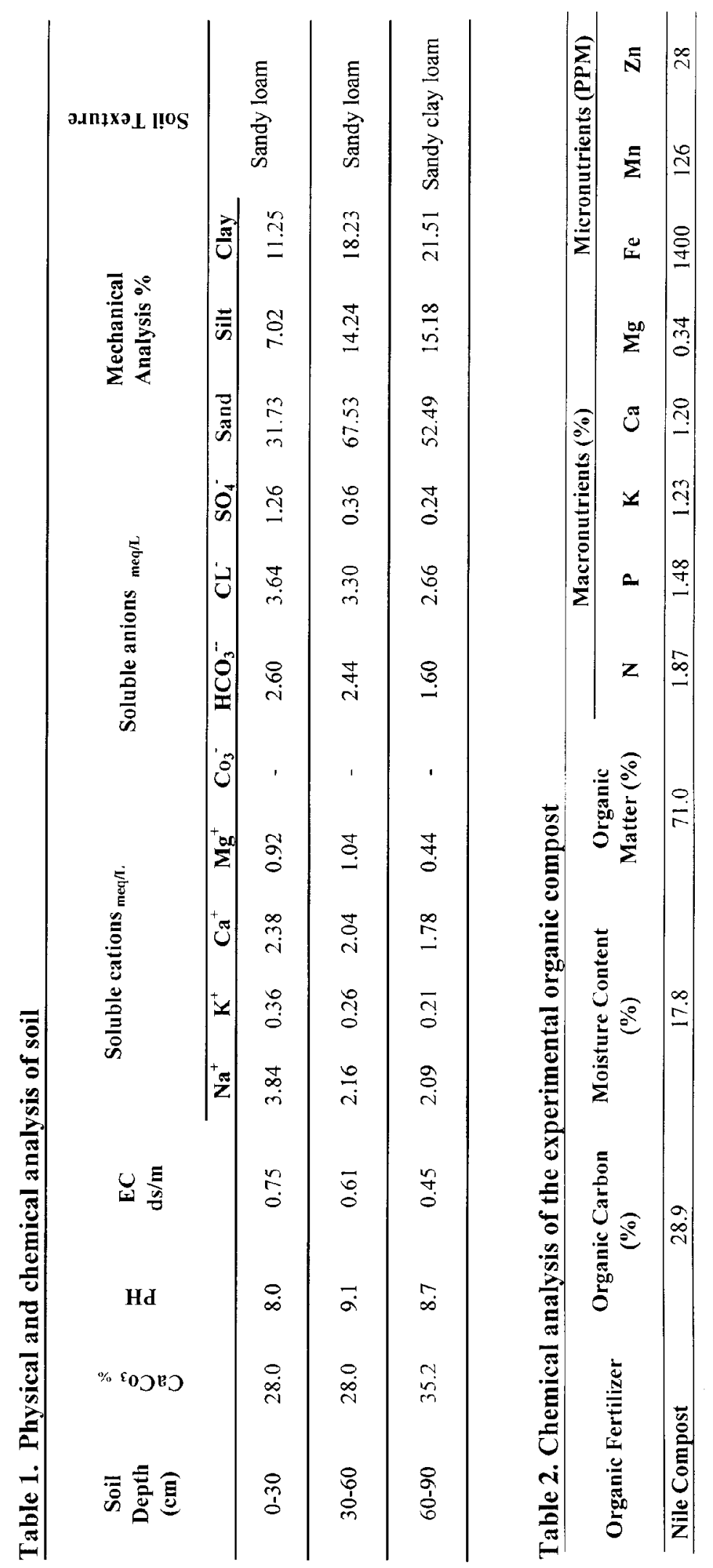


were determined colorimetrically according to Evenhuis (1976), and Murphy and Riley (1962), respectively. Potassium was determined against a standard by Flamephotometer (Corning 410). Data were statistically analyzed according to Snedecor and Cochran (1990) and L.S.D. test at 0.05 level was used for comparison between treatments.

\section{RESULTS AND DISCUSSIONS}

\section{Vegetative growth}

It is quite evident as shown in Table (3) that, all the evaluated growth measurements [average shoot length, number of leaves per shoot and leaf area] of Arabi pomegranate trees were statistically improved by all mineral and organic fertilization treatments either applied alone or in combinations as compared with the control treatment. In this respect, the combination representing $50 \%$ of the recommended rate of mineral nutrients $(\mathrm{NPK})+$ humic acid at higher concentration $(25 \mathrm{~kg} /$ tree $)$ was the most effective treatment as it gave the best results, while when combined with humic acid at lower concentration (12.5 g/tree) or compost at rate of $25 \mathrm{Kg}$ /tree were intermediate .However, the lowest values of the studied vegetative growth parameters except for ( no. of leaves / shoot in the $1^{\text {st }}$ season) were recorded when $50 \%$ of the recommended rate of mineral fertilizer NPK was added alone compared with the other treatments. No significant differences were noticed for this treatment for leaf area in both seasons. The data mostly followed the same trend of response during both seasons. Data also indicated that application of humic acid with both concentrations whether alone or in combination with $50 \%$ of the recommended rate of mineral fertilizer markedly increased growth parameters. These results may be due to the beneficial effect of organic fertilizer in increasing the availability of most nutrients and improving physical and chemical properties of soil in

favour of increasing nutritional status and growth of the tree could explain the present results for the necessity of using organic with mineral fertilizer (Nijjar, 1985). In addition, the microorganisms produce growth promoting substances which increase plant growth leading to increase photosynthetic rate (Nardi et al., 2002). The improving effect of using organic matter and in particular of humic acid on both plant metabolism and plant growth has been extensively investigated by (Lee and Bartlett, 1976; Tan and Tantiwiramanond, 1983; and Chen and Aviad, 1990). The results are in agreement with many investigators who worked on the effect of organic matter and reducing mineral fertilizers (Fernandez-Escobar et al., 1996 and Abou El-Khashab et al., 2005) on olive, (Safia, 2004) on pecan, (Athani et al., 2007(a\&b), Barbara et al., 2007 and Naik and Sri Hari Babu, 2007) on guava, (Eman et al., 2008) on grapevine and (El-Shenawi et al., 2008) on banana.

\section{Fruit set and yield}

As for the effect of organic and mineral fertilizer NPK whether alone or in combinations, it is clear from Table (4) that fruit set was significantly increased with application of all treatments in both seasons. In the meantime, yield as number or weight $(\mathrm{Kg} /$ tree ) of fruits were significantly increased with application of $100 \%$ of the recommended rate of NPK or with $50 \%$ of the recommended rate of NPK either with compost or humic acid in two different concentrations(12.5 or 25 $\mathrm{gm} /$ tree). Thus, $50 \%$ of the recommended rate of NPK + humic acid at $25 \mathrm{~g} /$ tree gave significantly the highest yield as number and weight of fruits $(\mathrm{kg})$ per tree than most of other treatments. This pronounced effect may be attributed to the favorable effect of mixed organic with mineral fertilizers which reserved the sufficient amounts

\section{Table 3. Effect of some organic and mineral fertilizers on some vegetative growth} parameters of Arabi pomegranate trees during 2007 and 2008 seasons

\begin{tabular}{lcccccc}
\multicolumn{1}{c}{ Treatments } & $\begin{array}{c}\text { Average Shoot length } \\
(\mathbf{c m})\end{array}$ & \multicolumn{2}{c}{$\begin{array}{c}\text { No. of } \\
\text { leaves/shoot }\end{array}$} & \multicolumn{2}{c}{$\begin{array}{c}\text { Leaf area } \\
(\mathbf{c m}) \mathbf{2}^{2}\end{array}$} \\
\cline { 2 - 8 } & $\mathbf{2 0 0 7}$ & $\mathbf{2 0 0 8}$ & $\mathbf{2 0 0 7}$ & $\mathbf{2 0 0 8}$ & $\mathbf{2 0 0 7}$ & $\mathbf{2 0 0 8}$ \\
\hline Control (Adopted Fertilization in the Farm) & 15.5 & 16.2 & 18.6 & 20.1 & 3.9 & 4.0 \\
\hline 100\% of NPK & 19.8 & 20.0 & 30.1 & 32.7 & 5.0 & 4.9 \\
\hline $50 \%$ of NPK & 17.6 & 18.0 & 27.8 & 29.3 & 4.4 & 4.4 \\
\hline Compost at 25 $\mathrm{kg} /$ tree & 18.0 & 19.1 & 26.3 & 28.4 & 4.5 & 4.4 \\
\hline Humic acid at 12.5 gm/tree $\mathrm{HA}_{1}$ & 18.5 & 18.5 & 29.2 & 29.0 & 4.5 & 4.6 \\
\hline Humic acid at 25 gm/tree $\mathrm{HA}_{2}$ & 19.0 & 19.6 & 30.0 & 30.2 & 4.9 & 4.9 \\
\hline 50\% of NPK + Compost & 21.0 & 23.2 & 33.1 & 34.9 & 6.1 & 6.0 \\
\hline
\end{tabular}




\begin{tabular}{|c|c|c|c|c|c|c|}
\hline $50 \%$ of $\mathrm{NPK}+\mathrm{HA}_{1}$ & 20.1 & 25.5 & 35.5 & 36.0 & 5.8 & 6.2 \\
\hline $50 \%$ of $\mathrm{NPK}+\mathrm{HA}_{2}$ & 23.4 & 24.0 & 36.7 & 37.8 & 6.5 & 6.7 \\
\hline L.S.D. & 1.2 & 1.1 & 1.09 & 1.35 & 0.53 & 0.54 \\
\hline
\end{tabular}

\begin{tabular}{|c|c|c|c|c|c|c|}
\hline \multirow{3}{*}{ Treatment } & \multirow{2}{*}{\multicolumn{2}{|c|}{ Fruit set \% }} & \multicolumn{4}{|c|}{ Yield /tree } \\
\hline & & & \multicolumn{2}{|c|}{ No. of fruits /tree } & \multicolumn{2}{|c|}{$\mathrm{Kg} /$ tree } \\
\hline & 2007 & 2008 & 2007 & 2008 & 2007 & 2008 \\
\hline Control (Adopted Fertilization in the Farm) & 19.90 & 19.50 & 122 & 116 & 23.63 & 23.50 \\
\hline $100 \%$ of NPK & 25.90 & 24.60 & 127 & 120 & 27.96 & 28.11 \\
\hline $50 \%$ of NPK & 25.10 & 22.00 & 122 & 118 & 25.51 & 25.00 \\
\hline Compost $25 \mathrm{~kg} /$ tree & 24.40 & 23.80 & 124 & 119 & 24.42 & 24.12 \\
\hline Humic acid at $12.5 \mathrm{gm} /$ tree $\mathrm{HA}_{1}$ & 24.00 & 23.50 & 123 & 119 & 24.83 & 25.35 \\
\hline Humic acid at $25 \mathrm{gm} /$ tree $\mathrm{HA}_{2}$ & 24.80 & 24.10 & 124 & 120 & 25.50 & 26.77 \\
\hline $50 \%$ of NPK + Compost & 30.50 & 29.40 & 132 & 132 & 31.00 & 32.22 \\
\hline $50 \%$ of $\mathrm{NPK}+\mathrm{HA}_{1}$ & 33.20 & 32.20 & 144 & 134 & 34.11 & 33.00 \\
\hline $50 \%$ of $\mathrm{NPK}+\mathrm{HA}_{2}$ & 35.40 & 34.30 & 149 & 147 & 36.08 & 36.55 \\
\hline L.S.D 0.05 & 1.21 & 1.56 & 3 & 5 & 4.20 & 3.10 \\
\hline
\end{tabular}

of $\mathrm{N}$ and $\mathrm{K}$ for plant development (Rosa et. al. 2004). Moreover, the addition of organic fertilizer to the soil encouraged proliferation of soil microorganisms, increased microbial populations and activity of microbial enzymes i.e.dehydrogenase, urease and nitrogenase (Maggioni et al.,1987). These results are in agreement with those obtained by Safia (2004), Saleh et al., (2006), Athani et al., (2007a\&b), Naik and Sri Hari Babu (2007), Eman et al., (2008) and EL-Shenawi et al.,(2008).They reported that adding humic acid or compost with mineral fertilizer significantly increased yield of different fruit species than organic fertilizer or mineral alone.

\section{Fruit physical and chemical properties:}

Data in Table (5) show the effect of mineral and organic fertilizer either alone or in combination on fruit physical and chemical properties of pomegranate trees in the two experimental seasons.

It is obvious that fruit weight (g), TSS and Anthocyanine were significantly increased by all the studied treatments as compared with control .The same observations were found in fruit length and diameter except, with $50 \%$ of NPK, compost or humic acid at lower concentration (12.5gm) alone, where the differences were too low to be significant .Acidity, however showed an opposite trend, while, V.C. as well as Tannin content were not significantly affected. It is noteworthy to mention that the effect of $50 \%$ of the recommended rate of NPK + higher humic supply $25 \mathrm{~g} /$ tree was more pronounced than the other treatments followed by $50 \%$ of the recommended rate of NPK + lower humic concentration $12.5 \mathrm{~g} /$ tree or with compost at rate of $25 \mathrm{Kg} /$ tree. The previous improvement in pomegranate yield and fruit characters may be attributed to the synergistic effect of the combination between organic and mineral amendments. This is due to the improvement of soil chemical and physical properties and available nutrients which in turn improves plant growth and fruit production and quality $(\mathrm{Li}, 1999$ and Itoo and Manivannan 2004). Finding of many investigators gave a real support to our results Neri et al.,(2002), Saleh et al., (2006), Athani et al., (2007a\&b), Naik and SriHariBabu (2007), El-Shenawi et al.,(2008) and Eman et al.,(2008).

\section{Leaf chlorophyll and mineral content:}

Data concerning the effect of the investigated treatments on leaf total chlorophyll and mineral content during the two experimental seasons are shown in Table (6). It is easy to say that, generally, all treatments resulted in enhancing leaf chlorophyll content and nitrogen percentage when compared with the control in both seasons, whereas $50 \%$ of the recommended NPK alone gave the lowest values when compared with other treatments. In the meantime, leaf $\mathrm{P}$ content increased by adding compost at rate of $25 \mathrm{~kg} /$ tree or humic acid at two concentrations either alone or when mixing with $50 \%$ of the recommended rate of NPK in the second season only. As for leaf K content, NPK fertilizers when applied alone at the full dose solely or at half dose and mixed with either compost or humic acid at both concentrations produced the richest leaves in $\mathrm{K}$ content in the second season only. Such effect may be attributed to the effect of organic matter and in particular of humic 


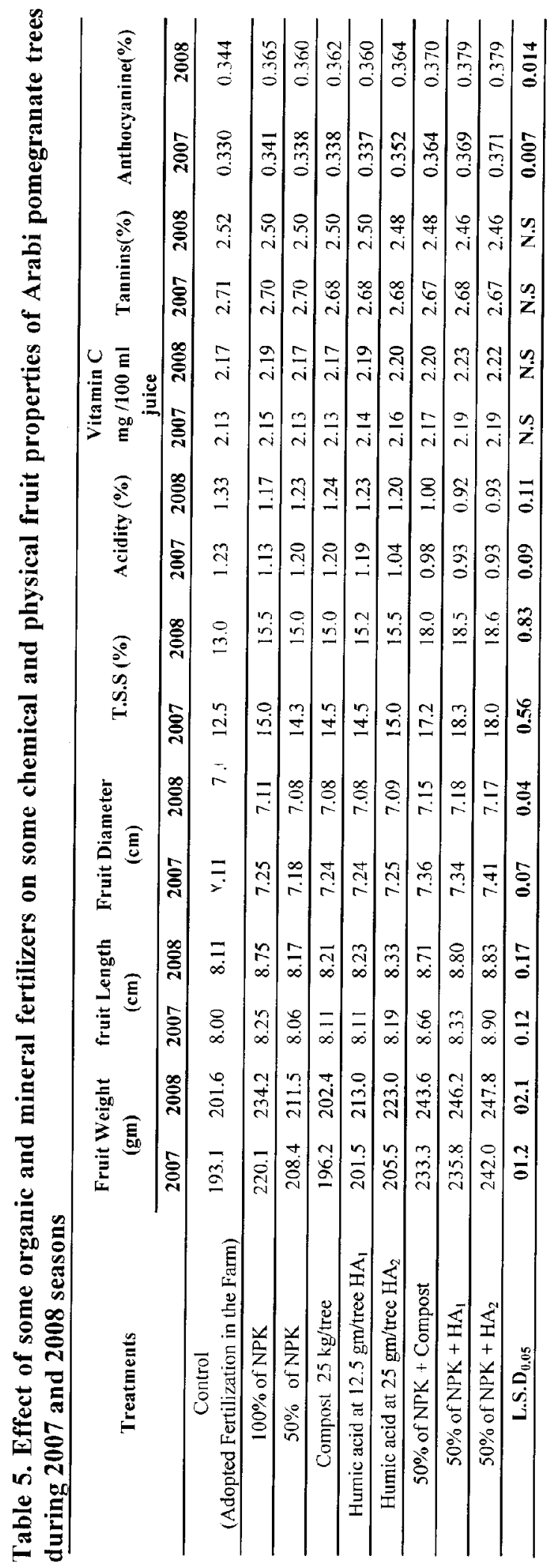


Table 6. Effect of some organic and mineral fertilizers on total leaf chlorophyll and some minerals content of Arabi pomegranate trees during 2007 and 2008 seasons

\begin{tabular}{|c|c|c|c|c|c|c|c|c|}
\hline \multirow[t]{2}{*}{ Treatments } & \multicolumn{2}{|c|}{$\begin{array}{c}\text { Total chlorophyll } \\
\mathrm{mg} / \mathrm{cm}^{2}\end{array}$} & \multicolumn{2}{|c|}{$\mathbf{N} \%$} & \multicolumn{2}{|c|}{$\mathbf{P \%}$} & \multicolumn{2}{|c|}{$\mathbf{K} \%$} \\
\hline & 2007 & 2008 & 2007 & 2008 & 2007 & 2008 & 2007 & 2008 \\
\hline Control (Adopted Fertilization in the Farm) & 4.90 & 4.13 & 1.82 & 1.90 & 0.12 & 0.13 & 0.93 & 0.95 \\
\hline $100 \%$ of NPK & 5.33 & 5.15 & 2.27 & 2.43 & 0.13 & 0.15 & 0.98 & 1.12 \\
\hline $50 \%$ of NPK & 5.02 & 4.90 & 1.87 & 1.95 & 0.13 & 0.15 & 0.94 & 0.97 \\
\hline Compost $25 \mathrm{~kg} /$ tree & 5.30 & 4.90 & 1.83 & 2.11 & 0.14 & 0.17 & 0.95 & 1.09 \\
\hline Humic acid at $12.5 \mathrm{gm} /$ tree $\mathrm{HA}_{1}$ & 5.11 & 4.95 & 1.86 & 2.10 & 0.13 & 0.16 & 0.96 & 1.07 \\
\hline Humic acid at $25 \mathrm{gm} /$ tree $\mathrm{HA}_{2}$ & 5.11 & 6.10 & 1.84 & 2.15 & 0.13 & 0.16 & 0.96 & 1.08 \\
\hline $50 \%$ of NPK + Compost & 5.19 & 6.00 & 2.00 & 2.21 & 0.15 & 0.19 & 1.00 & 1.09 \\
\hline $50 \%$ of $\mathrm{NPK}+\mathrm{HA}_{1}$ & 5.35 & 6.53 & 2.13 & 2.26 & 0.14 & 0.18 & 0.99 & 1.13 \\
\hline $50 \%$ of $\mathrm{NPK}+\mathrm{HA}_{2}$ & 6.55 & 6.58 & 2.20 & 2.32 & 0.14 & 0.18 & 1.00 & 1.15 \\
\hline L.S.D 0.05 & 0.28 & 0.41 & 0.06 & 0.13 & N.S & $\mathbf{0 . 0 3}$ & N.S & 0.07 \\
\hline
\end{tabular}

acid which able to stimulate root development, elongation and increased the production of thin and lateral roots that probably represents the most important effect of HA on plant development (Rosa et al., 2004) and largely affect absorption and assimilation of several inorganic nutrients, (Tan and Nopamornbodi, 1979, Albuzio et al., (1986), Tattini et al., 1991 and Andrade et al., 2004).

The present results concerning the effect of using combination with organic and mineral nutrients on increasing leaf chlorophyll and NPK are similar to those obtained by Murillo et al., (2005), Saleh et al., (2006), Athani et al., (2007b) Eman et al., (2008). However, Naik and SriHariBabu, (2007), and EL-Shenawi et al., (2008) found that leaf $\mathrm{N}$ remained almost the same before and after the trial. On the other hand, leaf $\mathrm{P}$ and $\mathrm{K}$ showed an increase after the termination of the trial due to various treatments except control.

\section{CONCOLUSION}

Generally it could be concluded that, applying organic matter (compost or humic acid) or with mineral fertilizers improved pomegranate growth, productivity and fruit quality. Also, it seems that fertilizing pomegranate trees with $50 \%$ of the recommended rate of NPK + humic acid at higher rate $(25 \mathrm{gm} /$ tree $)$ is the promising treatments under the same conditions of our study. Moreover, it reduces half of the amount of the recommended mineral fertilizers as well as soil.

\section{REFERENCES}

-Abd El-Naby, S.K.M. (2000). Effect of banana compost as organic manure on growth, nutrients status, yield and fruit

quality of Maghrabi banana. Assiut. J. of Agric. Sci.
3:101-114.

-Abou El-Khashab, A. M.;Safia,A.Taleb and Wafaa T.Saeed (2005).Aggezi and Koroneiki olive trees as affected by organic and bio-fertilizers, calcium citrate and potasseine. Arab Univ.,J.Agric.Sci. AinShams Univ., Cairo, 13(2), 419-440.

-Albuzio, A. ; Ferrari, G. and Nardi, S.,(1986). Effect of humic substances on nitrate uptake and assimilation in barley seedling.Can.J.Soil Sci., 66:731-736.

-Andrade, F.V.;Mendonca, E.S.;Silva. I.R. and Mateus.R.F.(2004).Low molecular weight and humic acids increase phosphorus uptake and corn growth in oxisoils. In:HUMIC SUBSTANCES AND SOIL AND WATER ENVIRONMENT, 2004, Sao pedro, Proceeding . Sao Pedro: Embrapa Inatrumentacao, P.211-214.

-A.O.A.C (1995): Association of Official Analytical Chemist's Official methods of analysis, $16^{\text {th }} \mathrm{Ed}$; Virginia, USA.

-Athani, S.I.; H.S.Prabhuraj, A.I.Ustad, G.S.K.Swamy, P.B.Patil andY.K .Kotikal (2007a). Effect of organic and inorganic fertilizers on growth, leaf major nutrient and chlorophyll content and yield of guava CV. Sardar.Acta Horticulturae. P.735.

-Athani,S.I.;A.I.Ustad,H.S.Prabhuraj,G.S.K.Swamy,P.B.Patil and Y.K. Kotikal (2007b).Influence of vermin-compost on growth, fruit yield and quality of guava cv. Sardar.Acta Horticulturae, P. 739

-Barbara, F.D.;M.S.Pereira;L. de Sa Ribeiro;J.L.Maia and 1.H.Bassoi (2007).Effect of humic substances and weather conditions on leaf biochemical changes of fertigated guava tree,during orchard establishment.Revista Brasileira de Fruticultyra.Vol.29 No.3 Jaboticabal.

-Chen, Y.and Aviad, T. Effect of humic substances on plant growth (1990). In: Maccarthy, p.; Clapp, E.E.; Malcom, 
R.L.; Bloom,P.R.(Ed.)(eds.) Humic substances in soil and crop sciences.

-El-Shenawi, M.R.; Hoda S.H.Aly and Badran M.A.F.(2008).Response of "GrandNain" banana to humic acid, potassium and magnesium fertilization. Alex. Sci. Exchange. J.Vol.29, No.4,P.244-251.

-Eman, A.A.AbdEl-Monem, M.M.S.Saleh and E.A.M.Mostafa (2008). Minimizing the quantity of mineral nitrogen fertilizers on grapevine by using humic acid,organic and biofertilizers. Res. J. of Agri. And Biological Sci. 4(1):46-50.

-Evenhuis, B. (1976). Nitrogen determination. Dept. Agric. Res.,Royal Tropical Inst.,Amsterdam.

-Evenhuis, B. and P.W.Dewaard(1980).Principles and practices in plant analysis. FAO soils Bull., 38(1):152163.

-Fernandez-Escobar, R.; M.Benlloch,D.Barranco,A.Duenas and J.A.Guterrez Ganan (1996). Response of olive trees to foliar application of humic substances extracted from Leonardite.Scientia Horticulturae, Vol.66, Issues 3-4, p.191-200.

-Haggag, Laila, F. (1996). Response of Picual olive tree in sandy soil to various forms of $\mathrm{N}$ fertilization (organic and chemical). Annals Agric. Sci. Ain-Shams Univ., Cairo, 41 (1):313-319.

-Hsia, C.L.; LUH, B.S. and Chickester, C.B. (1965). Anthocyanine in freestone peaches. J. food, Sci., 30:5-12.

-Itoo, B.A. and K.Manivannan (2004).Effect of macro and micronutrients in different forms in comparison with humic acid on growth, yield and quality of tomato (Lycopersicon esculentum Mill) cv.Annapurna.South Indian Horticulture.52 (1/6):342-346.

-Lee, Y, S., and Bartlett, R.J. (1976).Study of plant growth by humic substances.Soil Sci., 30:5-12.

-Li, N.; X.X. Wang and B.L.Lu (1999). Study of the effect of apple liquid fertilizer on the growth and fruit development of Starkrimson apple variety. (in Chinese). China Fruits No.4: 20-21(c.f. Hort.Abst.70, 5:3628).

-Liu, C.; R.J. Cooper and D.C. Bowman (1998). Humic acid application effects photosynthesis, root development and nutrient content of creeping bent grass. HortScience, 33(6) 1023-1025.

-Maggioni, A.; Varanini, Z. and Nardi, S. (1987). Action of soil humic matter on plant roots: stimulation of ion uptake and effects on $\left(\mathrm{Mg}^{2++} \mathrm{K}^{+}\right)$ATPase activity. Science of the Total Environment, Madison, Vol. 62, p. 355-363.

-Murillo,J. M.; Madejon,E.;Madejon,P. and Cabrera F., (2005).The response of wild olive to the addition of a fulvic-rich acid amendement to soils polluted by trace elements. Journal Arid Environments, London, V.63, p.284-303.

-Murphy, J. and J.P. Riley (1962).A modified single solution method for the determination of phosphorus in natural water. Ann.Chem.Acta, 27:31-38.
-Naik, M.H. and R. SriHariBabu (2007). Feasibility of organic farming in guava (Psidium guajava L.). Acta Horticulturae. No. 735.

-Nardi, S.; Pizzeghello, D.; Muscolo, A. and Vianello, A. (2002). Physiological effects of humic substances in plant growth. Soil Biology and Biochemistry, Exeter, Vol.34, no. 11 , p. 1527-1536.

-Neri, D.; E.M.Lodolini, G. Savini, P. Sabbatini,G. Bonanomi and F. Zucconi (2002). Foliar application of humic acids on strawberry (cv Onda). Acta Horticulturae 594.

-Nijjar, G.S. (1985). Nutrition of Fruit Tree. Mrs Usha Raj Kumar for kalyani Publishers New Delhi India, 306-308.

-O Donnell, R.W., (1973). The auxin- like effects of humic preparations from leonardite. Soil Science, (2) 6:106-112

-Petrovic, P.; Vitorovic, D. and Jablanovic, M. (1982). Investigations of biological effects of humic acid. Acta Biological Medical Experimental, Budapest, Vol.7, p.2125 .

-Pinton, R., Varanini,Z. and Vizzotto,G.(1992). Soil humic substances affect transport properties of tonoplast vesicles isolated from oat roots. Plant and Soil, The Hague, Vol.42,p. 203-210.

-Purchase, J. (1997).Humus, humic acid and natural chelating agents. Jpp/ informap.net.

-Rosa, C.M.; Castilhos, R.M.V.; Vahl, L.C. and Costa, P.F.P. (2004). Effect of fulvic acids on plant growth, root morphology and macronutrient uptake by oats. In: HUMIC SUbSTANCES AND SOIL WATER ENVIRONMEN · p.207-210.

-Russo, R.O. and G.P. Berlyn (1990). The use of organic biostimulants to help low input sustainable agriculture. J. Sustainable Agric. , 1(2):19-42 .

-Safia A.Abou-Taleb (2004).Effect of cattle manure and reducing mineral fertilizer on growth, fruit quality and nutrient content of pecan trees. Annals of Agric. Sci.Moshtohor,Vol. 42(3):1197-1214,(2004).

-Saleh, M.M.S.; S.EL-Ashry and A.M.Gomaa (2006). Performance of Thompson seedless grapevine as influenced by organic fertilizer,humic acid and biofertilizers under sandy soil conditions .Res.J. of Agri. and Biological Sci.,2(6):467-471.

-Seen, T.L. and A. R. Kingman (1973). A review of humus and humic acids. South Carolina Agricultural Experiment Station, Clemson, SC. Research Series Report No. 145.

-Snedecor, G.W.and W.G.Cochran (1990). Statistical methods $7^{\text {th }}$ ed. lowa. State. Univ. Press.Ames.Lowa.

-Tan, H., and Nopamornbodi, V. (1979).Effect of different levels of humic acids on nutrient content and growth of corn (Zea Mays L.). Plant and Soil, 51:283-287.

-Tan, H., and Tantiwiramanond, S.,(1983). Effect of humic acids on nodulation and dry matter production of soybean ,peanut and clover. Soil Sci.Soc. Am.J. 47:1121-1124.

-Tattini, M.; P.Bertoni; A.Landi and M.L.Traversi (1991).Effect of humic acids on growth and biomass 
partitioning of container grown olive plants.Acta Hort. 294:75-80.

-Winton, A.H. and Winton, K.B. (1945). Analysis of food Wiely,New York.p:572.
-Yadava, U.L. (1986). A rapid and non-destructive method to determine chlorophyll in intact leaves. HortSci, 21:14491450 .

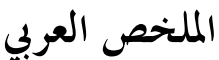

\section{تأثير إضافة بعض الأسمده العضويه والمعدنيه على نمو وإنتاجيه أشجار الرمان}

$$
\text { إيمان السيد كامل عبداللاه، ميرفت صديق سرور، وفاء علي السيسي }
$$

وقد كان هنــاك زيــادة بـسـيطة فن مختـوي الاوراق مــن

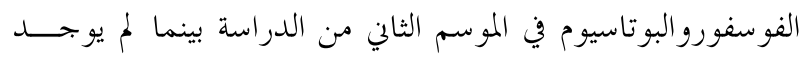

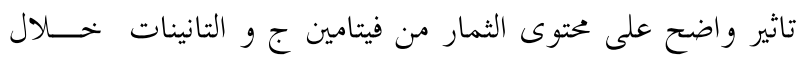

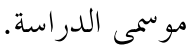

وكانت أكثر المعاملات تأثيرا هى إضافة نصف الجرعة من السماد المعدلن مع المادة العضوية سواء كانت حمض الهيومك بكلا

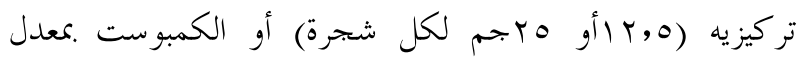
هبكج للشجرة على جميع المعاملات خلال موسمى الدراسة وادت

$$
\text { الى تحسن واضح ف جميع الصفات تحت الدراسة. }
$$

ومن الجدير بالذكر أن أستخدام المعاملات .0 \% من الجرعة

الموصى هها من التسميد المعدلن مع السماد العضوى بنوعيه تماثل اوني تزيد عن استخدام الجرعة الكاملة الموصى هها من التسميد المعدلن منفردا وتفيد هذه النتائج في تقليل معدلات السماد المعدنى المسببه للتلوث بالأضافة الى تحسين نمو ومحصول وصفات ثمار أشجار

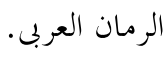

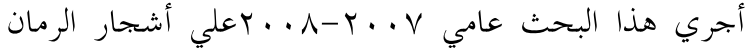
صنف العر بي عمرها جسنوات ومتزرعة في أرض رملية طميية كمزرعة خاصة علي طريق اسكندرية -مطروح الساحلي لدراسة. تأثير الاسمدة المختلفة: المعدنية(سلفات الامونيوم، سلفات

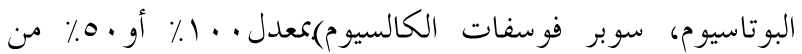
الجرعة الموصي هما وذلك لكل شجرة أو العضوية(حض الهيومك كعدله, rأو أو 0بم لكل شجرة أو كمبوست النيل .كعدل هrكج لكل شجرة) والخليط بينهما علي النمو وعقد الثمار والخصول ومحتوى الاوراق من العناصر وصفات جودة الثمار خلال

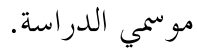

وقد أوضحت النتائح أن جميع المعاملات أدت الي زيادة واضحة في النمو الخضرى ومحتوى الاوراق من الكلوروفيل و النيترو جين عند مقارنتها بالكنترول.

كذلك وجد تحسن واضح في نسبة العقد والمصول وبعض صفات جودة الثمار(وزن وطول وعرض الثمار والمواد الصلبة الذائبه الكلية والانثوثيانين) بينما قلت الحموضة ودلك بالمقارنة كعاملة الكنترول. 